\title{
Parvaxanthines D-F and Asponguanosines C and D, Racemic Natural Hybrids from the Insect Cyclopelta parva
}

\author{
Heng Chen ${ }^{1,2,+}+\mathbb{D}$, Yong-Ming Yan ${ }^{2,+}$, Dai-Wei Wang ${ }^{2}$ and Yong-Xian Cheng ${ }^{1,2,3, *}$ \\ 1 Guangdong Pharmaceutical University, Guangzhou 510006, China; hengchen2021@foxmail.com \\ 2 School of Pharmaceutical Sciences, Shenzhen University Health Science Center, Shenzhen 518060, China; \\ yanym@szu.edu.cn (Y.-M.Y.); dweiwang@foxmail.com (D.-W.W.) \\ 3 Guangdong Key Laboratory for Functional Substances in Medicinal Edible Resources and Healthcare \\ Products, School of Life Sciences and Food Engineer, Hanshan Normal University, Chaozhou 521041, China \\ * Correspondence: yxcheng@szu.edu.cn \\ + These authors contributed equally to this work.
}

check for updates

Citation: Chen, H.; Yan, Y.-M.; Wang, D.-W.; Cheng, Y.-X. Parvaxanthines D-F and Asponguanosines C and D, Racemic Natural Hybrids from the Insect Cyclopelta parva. Molecules 2021, 26, 3531. https://doi.org/10.3390/ molecules26123531

Academic Editor: Akihito Yokosuka

Received: 20 May 2021

Accepted: 2 June 2021

Published: 9 June 2021

Publisher's Note: MDPI stays neutral with regard to jurisdictional claims in published maps and institutional affiliations.

Copyright: (C) 2021 by the authors Licensee MDPI, Basel, Switzerland. This article is an open access article distributed under the terms and conditions of the Creative Commons Attribution (CC BY) license (https:// creativecommons.org/licenses/by/ $4.0 /)$.
Abstract: Five new compounds including three pairs of enantiomeric xanthine analogues, parvaxanthines D-F (1-3), two new guanosine derivatives, asponguanosines $C$ and $D(6$ and 7$)$, along with two known adenine derivatives were isolated from the insect Cyclopelta parva. Racemic 1-3 were further separated by chiral HPLC. Their absolute configurations were assigned by spectroscopic and computational methods. It is interesting that all of these isolates are natural product hybrids. Antiviral, immunosuppressive, antitumor and anti-inflammatory properties of all the isolates were evaluated.

Keywords: Cyclopelta parva; insects; xanthine analogues; guanosine derivatives

\section{Introduction}

Natural products are important sources of bio-active drugs and play a significant role in the drug discovery and development process due to their structurally diverse and biological activities [1,2]. In the past decades, more attention has been given to microorganisms, and medicinal plants. However, chemical investigations on medicinal insects remain largely unknown $[3,4]$. Since ancient time, medicinal insects have been used to prevent and treat diseases in China. Whereas previous studies on insects mainly focused on biologically active proteins and peptides, little is known about their non-peptide natural products. In recent years, we have focused on unlocking small non-peptide molecules from medicinal insects. As a result, bio-active and structurally diverse substances have been characterized by us from several insects [5-11]. Cyclopelta parva is mainly distributed in southern China, such as in Hunan, Hubei, Guangdong and Yunnan provinces. Previous pharmacological studies revealed that $C$. parva possesses significant anticancer, antibacterial, antifatigue activities [12-14]. We have initiated an investigation on Aspongopus chinensis and identified structurally interesting substances [15-17], which belong to the same family as that of C. parva. These findings prompted us to conduct a study in C. parva. As a result, COX-2 inhibitory dihydroxydopamine derivatives have been isolated by our group [18]. As a part of our relay study on the title insect, five new (1-3, 6 and 7) and two known (4 and 5) base or nucleoside conjugates were isolated. This paper describes their isolation, structural identification, and biological evaluation (Figure 1). 

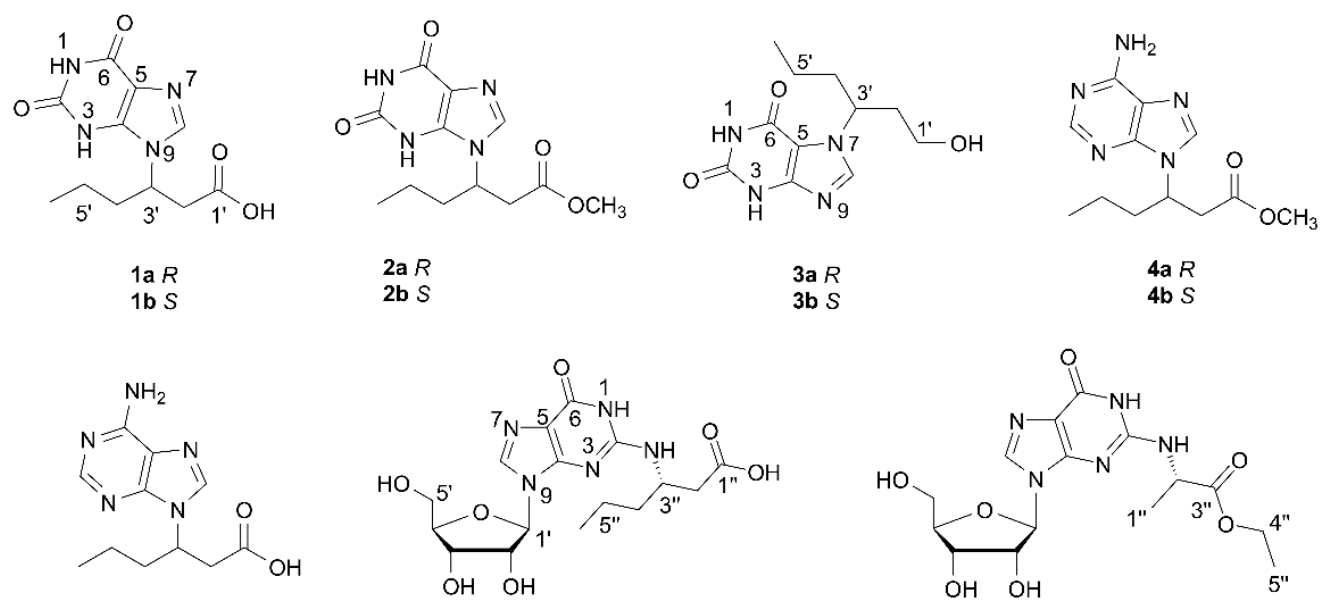

5a $R$
$5 \mathrm{~b} S$

Figure 1. The structures of compounds 1-7 from Cyclopelta parva.

\section{Results and Discussion}

\subsection{Structure Elucidation of the Compounds}

Parvaxanthine D (1) was assigned as $\mathrm{C}_{11} \mathrm{H}_{14} \mathrm{~N}_{4} \mathrm{O}_{4}$ by analysis of its HRESIMS ( $\mathrm{m} / \mathrm{z}$ $267.1078[\mathrm{M}+\mathrm{H}]^{+}$(calcd for $\mathrm{C}_{11} \mathrm{H}_{15} \mathrm{~N}_{4} \mathrm{O}_{4}, 267.1090$ ), indicating 7 degrees of unsaturation. The ${ }^{13} \mathrm{C}-\mathrm{NMR}$ along with the DEPT 135 experimental data of $\mathbf{1}$ (Table 1 ) show 11 carbon signals ascribed to one methyl, three methylenes, two methines (one olefinic), and five quaternary carbons (three carbonyl, two $\mathrm{sp}^{2}$ ). The ${ }^{1} \mathrm{H}-{ }^{1} \mathrm{H}$ COSY correlations of $\mathrm{H}-2^{\prime} / \mathrm{H}-$ $3^{\prime} / \mathrm{H}-4^{\prime} / \mathrm{H}-5^{\prime} / \mathrm{H}-6^{\prime}$ (Figure 2) alongside the HMBC correlation from H-2 ${ }^{\prime}$ to $\mathrm{C}-1^{\prime}\left(\Delta_{\mathrm{C}} 173.4\right)$ (Figure 2) indicates the presence of a hexanoic acid residue. Apart from this hexanoic acid residue fragment, the remaining NMR signals resemble those in a xanthine [19]. Careful comparison of the NMR data of $\mathbf{1}$ with parvaxanthine A [18], it revealed that they have similar structures, the only difference is that the hexanoic acid residue is connected to xanthine via $N-9$, the HMBC correlations of $\mathrm{H}-3^{\prime} / \mathrm{C}-4, \mathrm{C}-8$ supported this conclusion. This substance is a enantiomeric mixture, which was further purified by chiral HPLC to afford $(+)-\mathbf{1}(\mathbf{1 a})$ and $(-)-\mathbf{1}(\mathbf{1 b})$, and the absolute configurations were assigned as $3^{\prime} R$ for $\mathbf{1 a}$ by comparing the ECD spectrum of $\left(3^{\prime} R\right)-\mathbf{1}$, agreeing well with the experimental one of $(+)-\mathbf{1}$ (1a) (Figure 3). Thus, the structure of $\mathbf{1}$ was identified and named parvaxanthine D.

Table 1. ${ }^{1} \mathrm{H}-(600 \mathrm{MHz})$ and ${ }^{13} \mathrm{C}-\mathrm{NMR}(150 \mathrm{MHz})$ data of 1-3 ( $\Delta$ in ppm, $J$ in $\left.\mathrm{Hz}\right)$.

\begin{tabular}{|c|c|c|c|c|c|c|}
\hline \multirow{2}{*}{ Position } & \multicolumn{2}{|l|}{$1^{a}$} & \multicolumn{2}{|l|}{$2^{b}$} & \multicolumn{2}{|l|}{$3^{b}$} \\
\hline & $\Delta_{\mathrm{H}}$ & $\Delta_{\mathrm{C}}$ & $\Delta_{\mathbf{H}}$ & $\Delta_{\mathrm{C}}$ & $\Delta_{\mathbf{H}}$ & $\Delta_{\mathrm{C}}$ \\
\hline 2 & & $152.8, \mathrm{~s}$ & & $150.9, \mathrm{~s}$ & & $150.2, \mathrm{~s}$ \\
\hline 4 & & $142.6, \mathrm{~s}$ & & $140.6, \mathrm{~s}$ & & $151.1, \mathrm{~s}$ \\
\hline 5 & & $115.9, \mathrm{~s}$ & & $114.7, \mathrm{~s}$ & & $106.2, \mathrm{~s}$ \\
\hline 6 & & $159.9, \mathrm{~s}$ & & $157.9, \mathrm{~s}$ & & $155.4, \mathrm{~s}$ \\
\hline 8 & 7.99 (s) & $136.4, \mathrm{~d}$ & $7.89(\mathrm{~s})$ & $134.6, \mathrm{~d}$ & $8.03(\mathrm{~s})$ & $142.5, \mathrm{~d}$ \\
\hline $1^{\prime} \mathrm{a}$ & & $173.4, \mathrm{~s}$ & & $170.5, \mathrm{~s}$ & $3.31(\mathrm{~m})$ & $57.3, \mathrm{t}$ \\
\hline $1^{\prime} \mathrm{b}$ & & & & & $3.15(\mathrm{~m})$ & \\
\hline $2^{\prime} a$ & $2.99(\mathrm{dd}, 17.0,9.3)$ & $40.2, \mathrm{t}$ & $3.05(\mathrm{dd}, 17.0,9.4)$ & $38.4, \mathrm{t}$ & $2.12(\mathrm{~m})$ & $37.2, \mathrm{t}$ \\
\hline $2^{\prime} b$ & $2.97(\mathrm{dd}, 17.0,5.4)$ & & $3.00(\mathrm{dd}, 17.0,5.2)$ & & $1.98(\mathrm{~m})$ & \\
\hline $3^{\prime}$ & $4.70(\mathrm{~m})$ & $54.5, \mathrm{~d}$ & $4.71(\mathrm{~m})$ & $51.6, \mathrm{~d}$ & $4.63(\mathrm{~m})$ & $55.1, d$ \\
\hline $4^{\prime}$ & $1.91(\mathrm{~m})$ & $38.0, \mathrm{t}$ & $1.76(\mathrm{~m})$ & $36.3, \mathrm{t}$ & Ha: 1.90 (m)Hb: 1.70 (m) & $36.2, \mathrm{t}$ \\
\hline $5^{\prime} \mathrm{a}$ & $1.29(\mathrm{~m})$ & $20.2, \mathrm{t}$ & $1.18(\mathrm{~m})$ & $18.4, \mathrm{t}$ & $1.10(\mathrm{~m})$ & $18.7, \mathrm{t}$ \\
\hline $5^{\prime} \mathrm{b}$ & $1.18(\mathrm{~m})$ & & $1.00(\mathrm{~m})$ & & $1.02(\mathrm{~m})$ & \\
\hline $6^{\prime}$ & 0.93 (t-like, 7.3) & $13.9, \mathrm{q}$ & 0.81 (t-like, 7.3$)$ & $13.4, \mathrm{q}$ & 0.82 (t-like, 7.3$)$ & $13.5, \mathrm{q}$ \\
\hline $\mathrm{OCH}_{3}$ & & & $3.51(\mathrm{~s})$ & $51.5, \mathrm{q}$ & & \\
\hline
\end{tabular}

${ }^{\mathrm{a}}$ In methanol- $d_{4},{ }^{\mathrm{b}}$ In DMSO- $d_{6}$. 


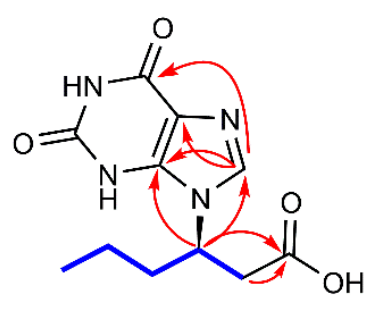

1

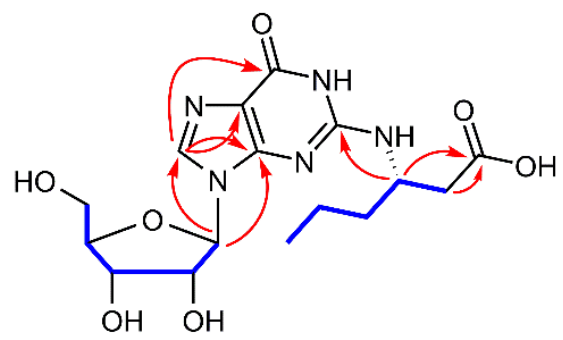

6

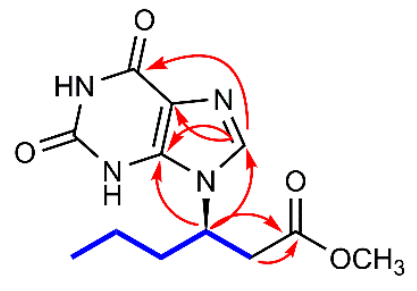

2<smiles>CCCC12CC3CC(CCO)(CC(C1)C31CCCC1)C2</smiles>

3

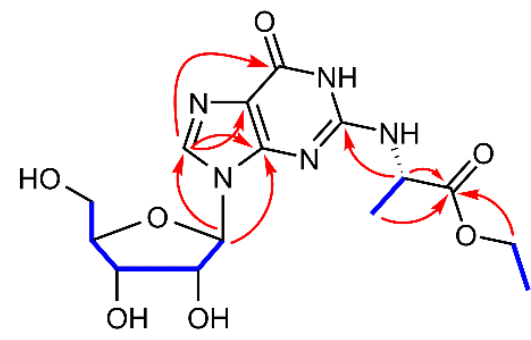

7

Figure 2. Key ${ }^{1} \mathrm{H}_{-}{ }^{1} \mathrm{H}$ COSY and HMBC correlations for 1-3 and 6, 7.
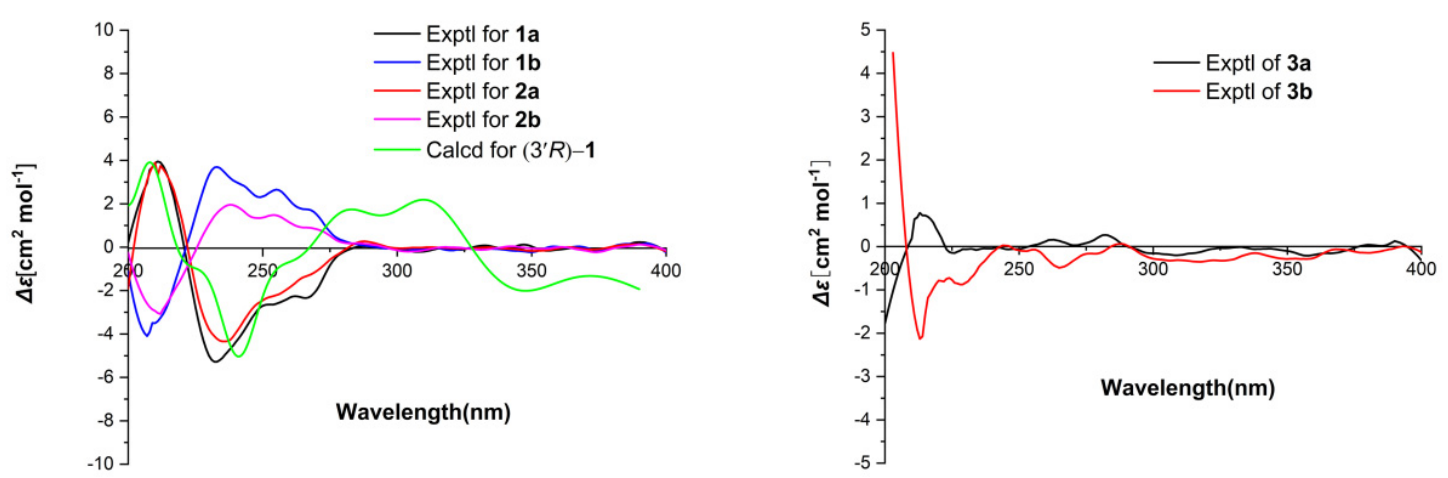

Figure 3. Comparison of the calculated ECD spectrum for $\left(3^{\prime} R\right)-1$ at B3LYP/6-311g $(\mathrm{d}, \mathrm{p})$ level with the experimental spectra of $\mathbf{1 a}, 1 \mathbf{b}, \mathbf{2} \mathbf{a}, 2 \mathbf{b}$ in $\mathrm{MeOH}$ (left), $\sigma=0.2 \mathrm{eV}$, shift $=-10 \mathrm{~nm}$. The experimental spectra of 3a,3b in $\mathrm{MeOH}$ (right).

Parvaxanthine $\mathrm{E}$ (2), with the molecular formula $\mathrm{C}_{12} \mathrm{H}_{16} \mathrm{~N}_{4} \mathrm{O}_{4}$, was established on the basis of its HRESIMS $\left(m / z 281.1242[\mathrm{M}+\mathrm{H}]^{+}\right.$(calcd for $\left.\mathrm{C}_{12} \mathrm{H}_{17} \mathrm{~N}_{4} \mathrm{O}_{4}, 281.1240\right)$. Detailed analysis of the NMR data of $\mathbf{2}$ with those of $\mathbf{1}$ demonstrated that they have similar structures, except the presence of an additional methoxy group in 2. The HMBC correlations of $\mathrm{OC}_{3} / \mathrm{C}-1^{\prime}$ indicates the position of the $\mathrm{CH}_{3} \mathrm{O}$ group in 2 . Thus the planar structure of 2 was assigned. Compound 2 was isolated as a racemic mixture. This was confirmed also by chiral HPLC analysis, which afforded to (+)-2 (2a) and (-)-2 (2b) by a Chiralpak IC column. Their absolute configurations were assigned as $3^{\prime} S$ for $\mathbf{2} \mathbf{b}$ by comparing its $C D$ spectrum with the experimental one of (-)-1 (1b) (Figure 3). In this way, the structure of $\mathbf{2}$ was identified and named parvaxanthine E.

Parvaxanthine F (3) was obtained as a white solid, and the molecule formula was determined as $\mathrm{C}_{11} \mathrm{H}_{16} \mathrm{~N}_{4} \mathrm{O}_{3}\left(\mathrm{~m} / z 253.1293[\mathrm{M}+\mathrm{H}]^{+}\right.$(calcd for $\mathrm{C}_{11} \mathrm{H}_{17} \mathrm{~N}_{4} \mathrm{O}_{3}, 253.1300$ ) by using a combination of HRESIMS, ${ }^{13} \mathrm{C}-\mathrm{NMR}$, and DEPT spectra. Compound 3 has a similar structure to parvaxanthine A [18], excepting that a caboxylic acid group in parvaxanthine A was replaced by a hydroxymethyl group in 3 , which gains supports from the ${ }^{1} \mathrm{H}^{-1} \mathrm{H}$ COSY correlations of $\mathrm{H}-1^{\prime}\left(\Delta_{\mathrm{Ha}} 3.31 ; \Delta_{\mathrm{Hb}} 3.15\right) / \mathrm{H}-2^{\prime} / \mathrm{H}-3^{\prime} / \mathrm{H}-4^{\prime} / \mathrm{H}-5^{\prime} / \mathrm{H}-6^{\prime} .3$ was also isolated as a racemic mixture, and chiral HPLC was performed to afford (+)-3 (3a) and 
$(-)-3(\mathbf{3 b})$. The absolute configurations were defined as $3^{\prime} S$ for $\mathbf{3 b}$ by comparing its $C D$ spectrum with that of (-)-parvaxanthine $\mathrm{A}$. The structure of $\mathbf{3}$ was therefore identified and named parvaxanthine $\mathrm{F}$.

Asponguanosine $\mathrm{C}(6)$ has the molecular formula $\mathrm{C}_{16} \mathrm{H}_{23} \mathrm{~N}_{5} \mathrm{O}_{7}$ deduced from the analysis of its HRESIMS $\left(\mathrm{m} / \mathrm{z} 398.1674[\mathrm{M}+\mathrm{H}]^{+}\right.$(calcd for $\left.\mathrm{C}_{16} \mathrm{H}_{24} \mathrm{~N}_{5} \mathrm{O}_{7}, 398.1670\right),{ }^{13} \mathrm{C}-\mathrm{NMR}$, and DEPT spectra. The ${ }^{13} \mathrm{C}-\mathrm{NMR}$ and DEPT spectra give 16 carbon signals attributed to $1 \times \mathrm{CH}_{3}, 4 \times \mathrm{CH}_{2}$ (three aliphatic), $6 \times \mathrm{CH}$ (one olefinic, five nitrogenated or oxygenated), and $5 \times \mathrm{C}$ (two carbonyl and three $\mathrm{sp}^{2}$ ). The ${ }^{1} \mathrm{H}-{ }^{1} \mathrm{H}$ COSY correlations of $\mathrm{H}-2^{\prime \prime} / \mathrm{H}-3^{\prime \prime} / \mathrm{H}-$ $4^{\prime \prime} / \mathrm{H}-5^{\prime \prime} / \mathrm{H}-6^{\prime \prime}$, in consideration of the chemical shift of C- $1^{\prime \prime}$ at $\Delta_{\mathrm{C}} 175.2$ and HMBCcorrelations of $\mathrm{H}-2^{\prime \prime}, \mathrm{H}-3^{\prime \prime} / \mathrm{C}-1^{\prime \prime}$, indicate the presence of a hexanoic acid residue. In addition, the other NMR signals resemble a guanosine moiety, which is connected to C- $3^{\prime \prime}$ via a $\mathrm{NH}$ bridge, which is supported by the HMBC observation of $\mathrm{H}-3^{\prime \prime} / \mathrm{C}-2$. Therefore, the planar structure of $\mathbf{6}$ was established as shown. $\mathbf{6}$ was isolated as an optically pure compound evidenced by chiral HPLC analysis. For the sugar moiety of $\mathbf{6}$, its configuration was determined to be D-ribose by acid hydrolysis followed by derivatization and comparison with the reference standard. With these data in hand, the absolute configuration of $\mathbf{6}$ at C-3" was assigned as $S$ by comparing the experimental ECD curve with the calculated one (Figure 4). As a result, the structure of $\mathbf{6}$ was deduced and named asponguanosine $C$.
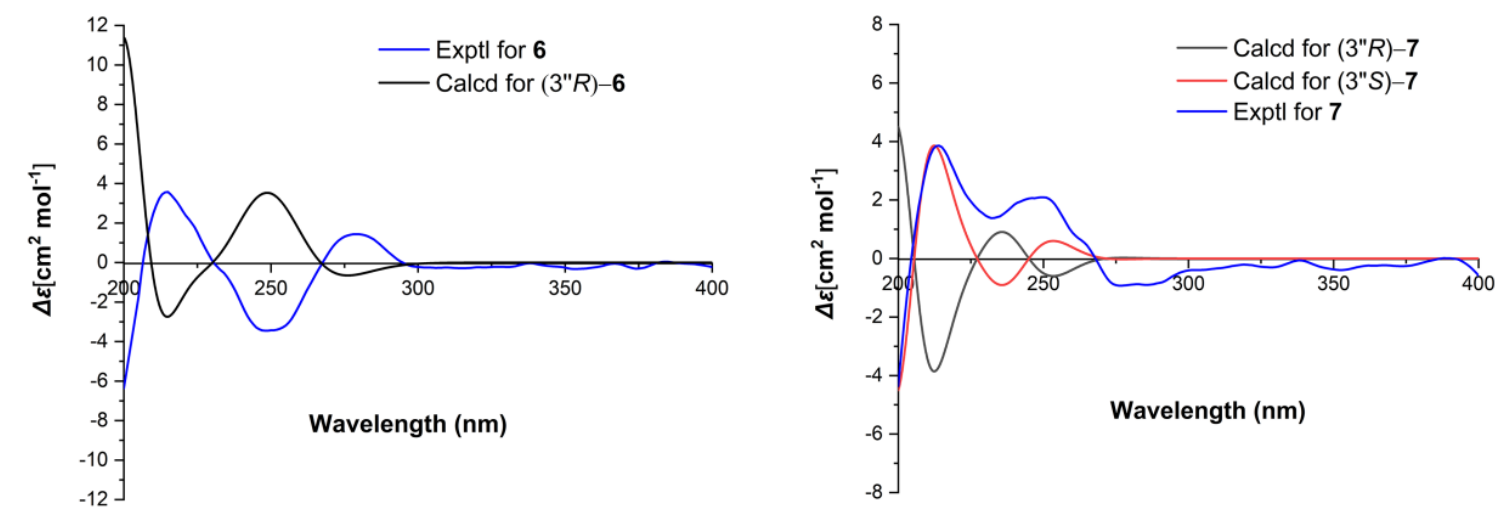

Figure 4. Comparison of the calculated ECD spectrum for $\left(3^{\prime \prime} R\right)-6$ with the experimental spectrum of 6 at B3LYP/6-31(d,p) level in $\mathrm{MeOH}$ (left). $\sigma=0.3 \mathrm{eV}$, shift $=+5 \mathrm{~nm}$. Comparison of the calculated ECD spectra for $\left(3^{\prime \prime} R\right)-7$ and $\left(3^{\prime \prime} S\right)-7$ with the experimental spectrum of 7 at B3LYP/6-31(d,p) level in $\mathrm{MeOH}$ (right). $\sigma=0.16 \mathrm{eV}$, shift $=0 \mathrm{~nm}$.

Asponguanosine $\mathrm{D}(7)$ was found to have the molecular formula $\mathrm{C}_{15} \mathrm{H}_{21} \mathrm{~N}_{5} \mathrm{O}_{7}$ deduced from its HRESIMS $\left(m / z 406.1329\right.$ [M + Na] ${ }^{+}$(calcd for $\left.\mathrm{C}_{15} \mathrm{H}_{21} \mathrm{~N}_{5} \mathrm{O}_{7} \mathrm{Na}, 406.1330\right),{ }^{13} \mathrm{C}-\mathrm{NMR}$, and DEPT spectra, indicating eight degrees of unsaturation. The ${ }^{1} \mathrm{H}-\mathrm{NMR}$ spectrum of 7 (Table 2) shows one proton signal at $\Delta_{\mathrm{H}} 8.38(\mathrm{~s}, \mathrm{H}-8)$. The ${ }^{13} \mathrm{C}-\mathrm{NMR}$ and DEPT spectra reveal 15 carbon signals classified into $2 \times \mathrm{CH}_{3}, 2 \times \mathrm{CH}_{2}$ (two oxygenated), $6 \times \mathrm{CH}$ (one olefinic, five nitrogen or oxygenated), and $5 \times \mathrm{C}$ (two carbonyls, three $\mathrm{sp}^{2}$ carbons). The NMR data of $\mathbf{7}$ are similar to those of $\mathbf{6}$, except for a difference in the side chain. The ${ }^{1} \mathrm{H}^{-}{ }^{1} \mathrm{H}$ COSY correlations of $\mathrm{H}-1^{\prime \prime} / \mathrm{H}-2^{\prime \prime}$ and $\mathrm{H}-4^{\prime \prime} / \mathrm{H}-5^{\prime \prime}$, and the HMBC correlations of $\mathrm{H}-1^{\prime \prime}$, $\mathrm{H}-2^{\prime \prime}$, and $\mathrm{H}-4^{\prime \prime} / \mathrm{C}-3^{\prime \prime}$, in consideration of the chemical shift of $\mathrm{C}-4^{\prime \prime}\left(\Delta_{\mathrm{C}} 62.8\right)$, indicate the presence of an ethyl propionate side chain, which is connected to the guanosine residue via a $\mathrm{NH}$ bridge as suggested by the HMBC correlations of $\mathrm{H}-2^{\prime \prime} / \mathrm{C}-2.7$ was also isolated as an optically pure compound. To clarify the absolute configuration of 7 , first hydrolysis followed by derivatization and comparison with the standards (D/L-ribose derivatives) allowed us to assign the sugar moiety in $\mathbf{7}$ as D-ribose. Next the ECD calculations were used to clarify the absolute configuration at C-2". It was found that the ECD spectrum of $\left(3^{\prime \prime} S\right)-7$ agrees well with the experimental one of 7 (Figure 4). As a consequence, the structure of 7 was identified as shown and named asponguanosine D. 
Table 2. ${ }^{1} \mathrm{H}-(600 \mathrm{MHz})$ and ${ }^{13} \mathrm{C}-\mathrm{NMR}(150 \mathrm{MHz})$ data of 6 and 7 in methanol- $d_{4}(\Delta$ in ppm, $J$ in $\mathrm{Hz})$.

\begin{tabular}{|c|c|c|c|c|}
\hline \multirow{2}{*}{ Position } & \multirow{2}{*}{$\begin{array}{c}6 \\
\Delta_{\mathrm{H}}\end{array}$} & \multicolumn{3}{|c|}{7} \\
\hline & & $\Delta_{\mathrm{C}}$ & $\Delta_{\mathrm{H}}$ & $\Delta_{\mathrm{C}}$ \\
\hline 2 & & $154.2, \mathrm{~s}$ & & 153.7, s \\
\hline 4 & & $152.2, \mathrm{~s}$ & & 152.1, s \\
\hline 5 & & $115.9, \mathrm{~s}$ & & 117.2, s \\
\hline 6 & & $158.3, \mathrm{~s}$ & & $158.7, \mathrm{~s}$ \\
\hline 8 & $8.45(\mathrm{~s})$ & $138.1, \mathrm{~d}$ & $8.38(\mathrm{~s})$ & $138.2, \mathrm{~d}$ \\
\hline $1^{\prime}$ & $5.93(\mathrm{brd}, 4.4)$ & $90.5, \mathrm{~d}$ & $5.91(\mathrm{brd}, 4.6)$ & $89.8, \mathrm{~d}$ \\
\hline $2^{\prime}$ & $4.64(\mathrm{t}$-like, 5.1) & $75.6, \mathrm{~d}$ & 4.54 (t-like,5.0) & $75.9, \mathrm{~d}$ \\
\hline $3^{\prime}$ & $4.33(\mathrm{t}-$ like, 5.1$)$ & $71.6, \mathrm{~d}$ & $4.30(\mathrm{t}-$ like, 5.0$)$ & $71.8, \mathrm{~d}$ \\
\hline $4^{\prime}$ & $4.10(\mathrm{~m})$ & $86.7, \mathrm{~d}$ & $4.08(\mathrm{~m})$ & $86.7, \mathrm{~d}$ \\
\hline $5^{\prime}$ & $\begin{array}{l}\text { Ha: } 3.88(\mathrm{dd}, 12.1,3.2) \\
\mathrm{Hb}: 3.77(\mathrm{dd}, 12.1,3.9)\end{array}$ & $62.7, \mathrm{t}$ & $\begin{array}{l}\text { Ha: } 3.85 \text { (dd, 12.1, 3.1); } \\
\text { Hb: } 3.74 \text { (dd, 12.1, 3.7) }\end{array}$ & $62.8, \mathrm{t}$ \\
\hline $1^{\prime \prime}$ & & $175.2, \mathrm{~s}$ & $1.51(\mathrm{~d}, 7.2)$ & $18.1, \mathrm{q}$ \\
\hline $2^{\prime \prime}$ & $\begin{array}{l}\text { Ha: } 2.62(\mathrm{dd}, 15.8,5.8) \\
\text { Hb: } 2.59(\mathrm{dd}, 15.8,6.1)\end{array}$ & $39.8, \mathrm{t}$ & $4.62(q, 7.2)$ & $51.2, \mathrm{~d}$ \\
\hline $3^{\prime \prime}$ & $4.42(\mathrm{~m})$ & $49.0, \mathrm{~d}$ & & $174.8, \mathrm{~s}$ \\
\hline $4^{\prime \prime}$ & $1.65(\mathrm{~m})$ & $37.6, \mathrm{t}$ & $4.23(\mathrm{~m})$ & $62.8, \mathrm{t}$ \\
\hline $5^{\prime \prime}$ & $1.45(\mathrm{~m})$ & $20.4, \mathrm{t}$ & $1.29(t, 1.7)$ & 14.6, q \\
\hline $6^{\prime \prime}$ & 0.97 (t-like, 7.4$)$ & $14.3, \mathrm{q}$ & & \\
\hline
\end{tabular}

It is interesting that all the isolates are natural product hybrids. Such a phenomenon has been found in Aspongopus chinensis [20]. In combination with the previous reports, it could be seen that alkylation of nitrogen is common in insect derived natural products. However, to the best of our knowledge, such compounds are not common in species beyond insects [21]. In addition, the reason that the insects synthesize these compounds by utilizing common nucleobases or nucleosides and a C6 unit remains unknown.

The known compounds ( 4 and 5) were identified to be aspongadenine A [15] and delicatuline B [22], respectively, by comparing their spectroscopic data with previously reported values.

\subsection{Biological Evaluation}

Natural product hybrids with profound biological activities have been described [23,24]. To explore the biological potential of such compounds, antiviral activity using vero cells, immunosuppressive activity in naive $\mathrm{T}$ cells, cytotoxic properties in human cancer cell lines (BGC-823, MDA-MB-231, HepG2, Kyse30), and LPS-induced pro-inflammatory expression in Raw264.7 cells were evaluated. Unfortunately, only compound 5a was found to have anti-inflammatory activity, and the others are inactive.

To investigate whether isolated compounds have biological importance, the biological activities of the isolates were evaluated. All of the isolated compounds except 5a were examined for their biologic activities on anti-inflammatory effects in RAW264.7 cells. To evaluate the cytotoxicity of compound $5 \mathbf{a}$, cells were incubated with different concentrations of compound $5 \mathrm{a}(0 \mu \mathrm{M}, 5 \mu \mathrm{M}, 10 \mu \mathrm{M}$ and $20 \mu \mathrm{M})$ for $24 \mathrm{~h}$. It was found that compound 5a did not affect the viability of the RAW264.7 cells by CCK-8 assay (Figure 5A). Then we measured the production of inflammatory cytokines treated with LPS in the presence or absence of compound 5a. The ELISA assay showed that compound 5a could suppress the production of IL-6 in LPS-stimulated RAW264.7 cells in a concentration-dependent manner (Figure 5B). In addition, since nucleobases, nucleosides, and the C6 unit are all common and structurally simple compounds, whether their hybrids play an essential role in ecological aspects needs further exploration. 
A

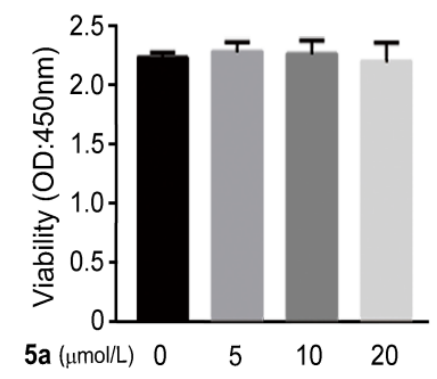

B

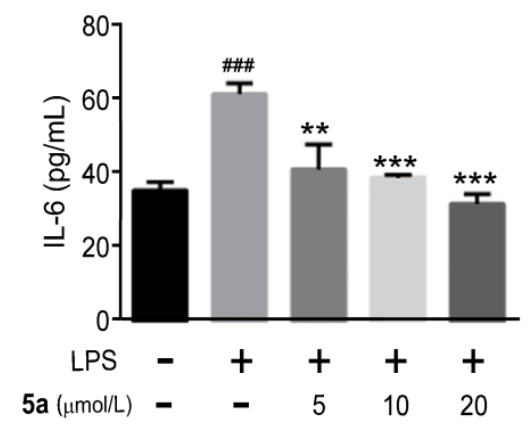

Figure 5. Compound 5a increased the effects of the pro-inflammatory cytokine IL-6. RAW264.7 cell proliferation in response to compound 5a at different doses assayed by CCK-8 assay (A). Compound 5a suppressed LPS-induced IL-6 expression in RAW 264.7 cells. The cells were pretreated with different concentrations of compound $5 \mathbf{a}$ for $2 \mathrm{~h}$ and then stimulated with $1 \mu \mathrm{g} / \mathrm{mL}$ LPS for $4 \mathrm{~h}$. Culture media were collected in order to measure IL-6 concentrations using an ELISA kit. Data represent mean \pm SEM values of three experiments. ${ }^{* *} p<0.01$ and ${ }^{* *} p<0.001$ compared with LPS alone. \#\#\# $p<0.001$ compared with DMSO alone (B).

\section{Experimental Section}

\subsection{General Procedures}

Optical rotations were recorded on a Horiba SEPA-300 polarimeter. NMR spectra were recorded on a Bruker AV-500 and AV-600 spectrometer (Bruker, Karlsruhe, Germany) with TMS as an internal standard. UV and CD spectra were obtained using a Chirascan instrument (Agilent Technologies, Santa Clara, CA, USA). HRESIMS were measured with a Shimadzu LC-20AD AB SCIEX triple TOF X500R MS spectrometer (Shimadzu Corporation, Tokyo, Japan). Macroporous adsorbents (Rohmhaas AMBERLITETM XAD 16N, America), Sephadex LH-20 (Amersham Biosciences, Uppsala, Sweden), YMC gel ODS-A-HG

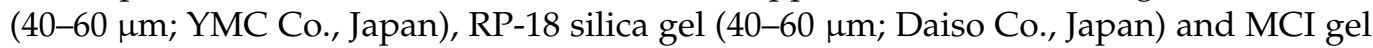
CHP 20P (75-150 $\mu \mathrm{m}$, Mitsubishi Chemical Industries, Tokyo, Japan) were used for column chromatography. Preparative HPLC was taken on a Chuangxin-Tongheng Chromatograph equipped with a Thermo Hypersil GOLD-C18 column $(250 \mathrm{~mm} \times 21.2 \mathrm{~mm}$, i.d., $5 \mu \mathrm{m})$. Semi-preparative HPLC separation were conducted on a Saipuruisi Chromatograph with a UV detector and a YMC-Pack ODS-A column $(250 \mathrm{~mm} \times 10 \mathrm{~mm}$, i.d., $5 \mu \mathrm{m})$. Chiral separation was carried out on a chiral HPLC equipped with a UV detector and a Daicel Chiralpak Phenomenex column (OOG-4762-E0 LUX®i-Amylose-1, $250 \mathrm{~mm} \times 4.6 \mathrm{~mm}$, i.d., $5 \mu \mathrm{m}$ ) or a Daicel Chiralpak column (IC, $250 \mathrm{~mm} \times 4.6 \mathrm{~mm}$, i.d., $5.5 \mu \mathrm{m}$; OD-H, $250 \mathrm{~mm} \times$ $4.6 \mathrm{~mm}$, i.d., $5 \mu \mathrm{m}$; AD-H, $250 \mathrm{~mm} \times 4.6 \mathrm{~mm}$, i.d., $5 \mu \mathrm{m}$ ) at a flow rate of $1.0 \mathrm{~mL} / \mathrm{min}$.

\subsection{Insect Material}

C. parva was purchased and identified by Prof. De-Po Yang at School of Pharmaceutical Sciences, Sun Yat-Sen University. The material was purchased from Hunan Zhenxing Co. Ltd. for Chinese Materia Medica, Changsha, China, in December 2017. A voucher specimen (No. CHYX0628) is deposited at the School of Pharmaceutical Sciences, Shenzhen University, China.

\subsection{Extraction and Isolation}

The air-dried powdered C. parva $(45 \mathrm{~kg}$ ) was extracted with $80 \%$ aqueous $\mathrm{EtOH}$ $(3 \times 270 \mathrm{~L}, 24 \mathrm{~h}$ each) at room temperature. The combined extracts were concentrated to obtain a crude extract, which was suspended in water and successively partitioned with petroleum ether and ethyl acetate. The water-soluble extracts $(4.0 \mathrm{~kg})$ were divided into 6 parts (Fr.1-Fr.6) by using a macroporous adsorbents AMBERLITE XAD 16N column eluted with gradient aqueous EtOH (10:90-100:0). Fr.2 (170 g) was isolated by a MCI 
gel CHP 20P column eluted with gradient aqueous $\mathrm{MeOH}(2: 98-60: 40)$ to afford nine fractions (Fr.2.1-Fr.2.9). Fr.2.4 (25.8 g) was subjected to an ODS column on MPLC system eluted with gradient aqueous $\mathrm{MeOH}(2: 98-60: 40$, flow rate: $20 \mathrm{~mL} / \mathrm{min})$ to afford seven fractions (Fr.2.4.1-Fr.2.4.7). Fr.2.4.3 (4.89 g) was subjected to gel filtration on Sephadex $\mathrm{LH}-20\left(\mathrm{MeOH} / \mathrm{H}_{2} \mathrm{O}, 75: 25\right)$ to give seven portions (Fr.2.4.3.1-Fr.2.4.3.7). Fr.2.4.3.5 (1.09 g) was separated by using a MCI gel CHP 20P column eluted with gradient aqueous $\mathrm{MeOH}$ (5:95-45:55) to provide nine portions (Fr.2.4.3.5.1-Fr.2.4.3.5.9). Fr.2.4.3.5.4 (284 mg) was separated by preparative HPLC (MeOH $/ \mathrm{H}_{2} \mathrm{O}$ with $0.04 \%$ TFA, $3-15 \%$, flow rate: $10 \mathrm{~mL} / \mathrm{min}$ ) to yield four subfractions (Fr.2.4.3.5.4.1-Fr.2.4.3.5.4.4). Fr.2.4.3.5.4.3 (95.6 mg) was purified by semi-preparative HPLC (MeOH/ $\mathrm{H}_{2} \mathrm{O}$ with $0.04 \%$ TFA, $22: 78$, flow rate: $3 \mathrm{~mL} / \mathrm{min}$ ) to obtain $2\left(t_{R}=25.2 \mathrm{~min}, 4.30 \mathrm{mg}\right)$ and $\mathbf{1}\left(t_{R}=34.1 \mathrm{~min}, 12.31 \mathrm{mg}\right)$. Compound $\mathbf{1}$ is a racemate that was separated by semi-preparative HPLC on a chiral phase by equipping with a Daicel Chiralpak IC (n-hexane/EtOH containing 0.04\% TFA, 45:55, flow rate: $1.0 \mathrm{~mL} / \mathrm{min}$ ) to afford $(+)-\mathbf{1}\left(t_{R}=9.4 \mathrm{~min}, 4.76 \mathrm{mg}\right), \mathbf{1 a}$; and $(-)-\mathbf{1}\left(t_{R}=18.8 \mathrm{~min}, 4.87 \mathrm{mg}\right), \mathbf{1 b}$. Compound 2 is also a racemate, which was separated by semi-preparative HPLC on a chiral phase equipping with a Daicel Chiralpak IC (n-hexane/EtOH, $40: 60$, flow rate: $1.0 \mathrm{~mL} / \mathrm{min}$ ) to afford $(+)-2\left(t_{R}=15.0 \mathrm{~min}, 1.80 \mathrm{mg}\right), \mathbf{2 a}$; and $(-)-\mathbf{2}\left(t_{R}=33.2 \mathrm{~min}, 1.84 \mathrm{mg}\right), \mathbf{2 b}$.

Fr.2.5 (26.8 mg) was divided into seven subfractions (Fr.2.5.1-Fr.2.5.7) by an ODS column on a MPLC system eluted with gradient aqueous $\mathrm{MeOH}(5: 95-60: 40$, flow rate: $20 \mathrm{~mL} / \mathrm{min})$. Fr.2.5.4 (6.63 g) was separated by a RP-18 column $\left(\mathrm{MeOH} / \mathrm{H}_{2} \mathrm{O}, 8: 92-45: 55\right)$ to give seven portions (Fr.2.5.4.1-Fr.2.5.4.7). Fr.2.5.4.3 (2.6 g) was subjected to gel filtration on Sephadex LH-20 (MeOH/ $\left.\mathrm{H}_{2} \mathrm{O}, 75: 25\right)$ to give five portions (Fr.2.5.4.3.1-Fr.2.5.4.3.5). Fr.2.5.4.3.5 (167.3 mg) was purified by semi-preparative HPLC $\left(\mathrm{MeOH} / \mathrm{H}_{2} \mathrm{O}, 28: 72\right.$, flow rate: $3 \mathrm{~mL} / \mathrm{min})$ to obtain $3\left(t_{\mathrm{R}}=27.1 \mathrm{~min}, 6.76 \mathrm{mg}\right)$. Racemic 3 was separated by semipreparative HPLC on a chiral phase by equipping with a Daicel Chiralpak OD-H (nhexane $/{ }^{i} \mathrm{PrOH}$ with $0.04 \%$ TFA, $85: 15$, flow rate: $\left.1.0 \mathrm{~mL} / \mathrm{min}\right)$ to afford $(+)-3\left(\mathrm{t}_{\mathrm{R}}=17.5 \mathrm{~min}\right.$, $3.54 \mathrm{mg}), \mathbf{3 a}$; and $(-)-3\left(\mathrm{t}_{\mathrm{R}}=23.6 \mathrm{~min}, 2.71 \mathrm{mg}\right)$, 3b. Fr.2.5.4.4 (1.86 g) was separated by using Sephadex LH-20 (MeOH/ $\left.\mathrm{H}_{2} \mathrm{O}, 70: 30\right)$ followed by semi-preparative HPLC $\left(\mathrm{MeCN} / \mathrm{H}_{2} \mathrm{O}\right.$ with $0.04 \%$ TFA, $11: 89$, flow rate: $3 \mathrm{~mL} / \mathrm{min})$ to obtain $6\left(t_{\mathrm{R}}=20.6 \mathrm{~min}, 3.41 \mathrm{mg}\right.$ ) and $7\left(t_{R}=24.8 \mathrm{~min}, 2.08 \mathrm{mg}\right)$. Fr.2.5.3 (6.3 g) was separated by using Sephadex LH-20 $\left(\mathrm{MeOH} / \mathrm{H}_{2} \mathrm{O}, 75: 25\right)$ followed by a RP-18 column $\left(\mathrm{MeOH} / \mathrm{H}_{2} \mathrm{O}, 5: 95-35: 65\right)$ to produce three portions (Fr.2.5.3.1-Fr.2.5.3.3). Fr.2.5.3.3 (2.0 g) was separated by using Sephadex $\mathrm{LH}-20\left(\mathrm{MeOH} / \mathrm{H}_{2} \mathrm{O}, 70: 30\right)$ followed by semi-preparative HPLC $\left(\mathrm{MeOH} / \mathrm{H}_{2} \mathrm{O}\right.$ with $0.04 \%$ TFA, 20:80, flow rate: $3 \mathrm{~mL} / \mathrm{min}$ ) to obtain 4 and 5 . Compound 4 is a racemate that was separated by semi-preparative HPLC on a chiral phase equipped with a Daicel Chiralpak IC (n-hexane $/ \mathrm{EtOH}, 65: 35$, flow rate: $1.0 \mathrm{~mL} / \mathrm{min})$ to afford $(+)-4\left(t_{R}=15.3 \mathrm{~min}, 0.88 \mathrm{mg}\right)$, 4a; and $(-)-\mathbf{4}\left(t_{R}=16.4 \mathrm{~min}, 1.3 \mathrm{mg}\right), \mathbf{4 b}$. Compound $\mathbf{5}$ is a racemate that was separated by semi-preparative HPLC on a chiral phase equipped with a Daicel Chiralpak IC (nhexane $/ \mathrm{EtOH}, 30: 70$, flow rate: $1.0 \mathrm{~mL} / \mathrm{min})$ to afford $(+)-5\left(t_{\mathrm{R}}=6.3 \mathrm{~min}, 2.72 \mathrm{mg}\right), 5 \mathrm{a}$; and $(-)-5\left(t_{R}=9.3 \mathrm{~min}, 1.98 \mathrm{mg}\right), 5 \mathbf{b}$ respectively.

\subsection{Compound Characterization Data}

Parvaxanthine D (1): white power; UV $(\mathrm{MeOH}) \lambda \max (\log \varepsilon) 261$ (3.93), 235 (3.89), $200(4.20) \mathrm{nm} ;\left\{[\alpha]^{20} \mathrm{D}-11.8(c 0.03, \mathrm{MeOH}) ; \mathrm{CD}(\mathrm{MeOH}) \Delta \varepsilon_{209}+1.15, \Delta \varepsilon_{233}-1.42 ; \mathbf{1 a}\right\} ;$ $\left\{[\alpha]^{20}{ }_{\mathrm{D}}+6.3(\mathrm{c} 0.03, \mathrm{MeOH}) ; \mathrm{CD}(\mathrm{MeOH}) \Delta \varepsilon_{209}-0.86, \Delta \varepsilon_{233}+1.03 ; 1 \mathbf{b}\right\} ;$ HRESIMS $(\mathrm{m} / \mathrm{z}$ 267.1078 [M + H] ${ }^{+}\left(\right.$calcd for $\left.\mathrm{C}_{11} \mathrm{H}_{15} \mathrm{~N}_{4} \mathrm{O}_{4}, 267.1090\right) ;{ }^{1} \mathrm{H}$ and ${ }^{13} \mathrm{C}$-NMR data, see Table 1 .

Parvaxanthine E (2): white solid; UV (MeOH) $\lambda \max (\log \varepsilon) 258$ (3.99), 241 (3.93), 200 (4.34) nm; $\left\{[\alpha]^{20} \mathrm{D}-3.2(c 0.03, \mathrm{MeOH}) ; \mathrm{CD}(\mathrm{MeOH}) \Delta \varepsilon_{208}+1.10, \Delta \varepsilon_{233}-1.23 ; 2 \mathbf{a}\right\} ;\left\{[\alpha]^{20}{ }_{\mathrm{D}}\right.$ + 6.7 ( $c$ 0.02, MeOH), $\left.\mathrm{CD}(\mathrm{MeOH}) \Delta \varepsilon_{208}-1.26, \Delta \varepsilon_{233}+0.45 ; \mathbf{2 b}\right\}$, HRESIMS $(m / z 281.1240$ $[\mathrm{M}+\mathrm{H}]^{+}$(calcd for $\left.\mathrm{C}_{12} \mathrm{H}_{17} \mathrm{~N}_{4} \mathrm{O}_{4}, 281.1244\right) ;{ }^{1} \mathrm{H}$ and ${ }^{13} \mathrm{C}-\mathrm{NMR}$ data, see Table 1.

Parvaxanthine F (3): white solid; UV (MeOH) $\lambda \max (\log \varepsilon) 269$ (3.70), $201(4.22) \mathrm{nm}$; $\left\{[\alpha]^{20}{ }_{\mathrm{D}}+7.7(c 0.03, \mathrm{MeOH}) ; \mathrm{CD}(\mathrm{MeOH}) \Delta \varepsilon_{214}+0.42 ; 3 \mathbf{a}\right\} ;\left\{[\alpha]_{\mathrm{D}}{ }^{20}-10.0(c 0.02, \mathrm{MeOH}) ;\right.$ $\left.\mathrm{CD}(\mathrm{MeOH}) \Delta \varepsilon_{214}-0.20 ; 3 \mathbf{b}\right\} ;$ HRESIMS $\left(m / z 253.1296[\mathrm{M}+\mathrm{H}]^{+}\left(\right.\right.$calcd for $\mathrm{C}_{11} \mathrm{H}_{17} \mathrm{~N}_{4} \mathrm{O}_{3}$, 253.1295); ${ }^{1} \mathrm{H}$ and ${ }^{13} \mathrm{C}$-NMR data, see Table 1. 
Asponguanosine C (6): yellow gum; UV (MeOH) $\lambda \max (\log \varepsilon) 255$ (3.80), 200 (4.16) $\mathrm{nm} ;\left\{[\alpha]^{20} \mathrm{D}+108.3(c 0.02, \mathrm{MeOH}) ; \mathrm{CD}(\mathrm{MeOH}) \Delta \varepsilon_{201}-2.33, \Delta \varepsilon_{216}+1.48, \Delta \varepsilon_{249}-1.41\right.$, $\left.\Delta \varepsilon_{281}+0.58 ; 6\right\} ;$ HRESIMS $\left(m / z 398.1675[\mathrm{M}+\mathrm{H}]^{+}\left(\right.\right.$calcd for $\left.\mathrm{C}_{16} \mathrm{H}_{24} \mathrm{~N}_{5} \mathrm{O}_{7}, 398.1670\right) ;{ }^{1} \mathrm{H}$ and ${ }^{13} \mathrm{C}$-NMR data, see Table 2.

Asponguanosine D (7): yellow gum; UV (MeOH) $\lambda \max (\log \varepsilon) 254$ (3.94), 200 (4.25) nm; $\left\{[\alpha]^{20}{ }_{\mathrm{D}}-17.4\right.$ (c 0.02, MeOH); CD (MeOH) $\left.\Delta \varepsilon_{200}-1.90, \Delta \varepsilon_{214}+1.54, \Delta \varepsilon_{276}-0.38 ; 7\right\}$; HRESIMS $\left(m / z 406.1329[\mathrm{M}+\mathrm{Na}]^{+}\right.$(calcd for $\mathrm{C}_{15} \mathrm{H}_{21} \mathrm{~N}_{5} \mathrm{O}_{7} \mathrm{Na}, 406.1333$ ); ${ }^{1} \mathrm{H}$ and ${ }^{13} \mathrm{C}-\mathrm{NMR}$ data, see Table 2.

\subsection{Acid Hydrolysis and Preparation of Sugar Derivatives of Compounds 6 and 7}

Compounds 6 or 7 (each $0.5 \mathrm{mg}$ ) was submitted to hydrolysis with $0.8 \mathrm{~mL}$ of $6 \mathrm{~N}$ $\mathrm{HCl}$ at $60{ }^{\circ} \mathrm{C}$ for $1.5 \mathrm{~h}$. The reaction mixtures were concentrated and L-cysteine methyl ester in pyridine $(0.8 \mathrm{~mL})$ solution was added to it and reflected at $60{ }^{\circ} \mathrm{C}$ for $1 \mathrm{~h}$. Then 2-methylphenyl isothiocyanate was added to the reaction mixtures and further heated for one more hour. In the same way, the standards ribose D and L were also derivatized and the reaction mixtures were directly analyzed by RP-18 HPLC [YMC-Pack ODS-A column $(250 \mathrm{~mm} \times 4.6 \mathrm{~mm}$, i.d., $5 \mu \mathrm{m}) ; \mathrm{MeOH} / \mathrm{H}_{2} \mathrm{O}\left(0.05 \% \mathrm{CF}_{3} \mathrm{COOH}\right), 40: 60$; flow rate: $0.8 \mathrm{~mL} / \mathrm{min}]$. The retention times $\left(\mathrm{t}_{R}\right)$ of the derivatives of standard D-ribose and L-ribose were determined at $16.8 \mathrm{~min}$ and $13.3 \mathrm{~min}$, respectively. By the comparison of retention times $\left(t_{R}\right)$ of compounds 6 and 7 derivatives with the standards (D/L-ribose derivatives), the ribose in compounds 6 and 7 were determined to be D-form (see Supplementary Materials) [25,26].

\subsection{Computational Methods}

Molecular Merck force field (MMFF) and DFT/TDDFT were calculated with Spartan'14 software package and Gaussian 09 program package. Electronic circular dichroism (ECD) calculations were conducted at the B3LYP SCRF (PCM)/6-311G(d,p) level and the CD spectra were produced by the program SpecDis 1.62 [27].

\subsection{Antiviral Activity Assay}

Antiviral activity [28] was determined by plaque assay using monolayer cultures of African green monkey kidney (Vero) cells in 96-well culture plates with $1 \times 10^{4}$ cells/well. After 24-h incubation, the growth medium (RPMI-1640 medium supplemented with 10\% Fetal Bovine Serum (FBS)) was discarded, and the cells incubated with compounds were diluted to 3 series concentrations $(50.00,25.00$, and $12.50 \mu \mathrm{M})$ in maintenance solution (RPMI-1640 medium supplemented with $2 \%$ FBS). The experiment was repeated three times with 7 replicates for each concentration. The negative control wells represented Vero cells with maintenance medium without virus. All cells were cultured at $37{ }^{\circ} \mathrm{C}$ in a $5 \%$ $\mathrm{CO}_{2}$ atmosphere for $72 \mathrm{~h}$ and the cytopathic condition was observed under an inverted microscope. When the cytopathic effect in the virus control group (positive control) reached more than 75\%, we observed and recorded the cytopathic effect (CPE) of each well (see Supplementary Materials).

\subsection{Immunosuppressive Activity Assay}

The cytotoxicity of the compounds $(20 \mu \mathrm{M})$ on resting lymphocytes from C57/BL6 mice was determined. Spleen cells $\left(5 \times 10^{5} /\right.$ well $)$ were incubated for $24 \mathrm{~h}$ in the presence of various concentrations of compounds. Cell viability was measured at $570 \mathrm{~nm}$ by MTT uptake. T lymphocytes obtained from C57/BL6 mice were cultured with compounds $(20 \mu \mathrm{M})$ for $4 \mathrm{~h}$, then treated with murine IFN- $\gamma(5 \mathrm{ng} / \mathrm{mL})$ for $30 \mathrm{~min}$. After the incubation, proteins were extracted and assessed by Western blot analysis. Mouse T lymphocytes $\left(2 \times 10^{5} /\right.$ well) obtained from splenocytes of C57/BL6 mice were stimulated by Con A $(5 \mu \mathrm{g} / \mathrm{mL})$ for $48 \mathrm{~h}$, in the presence of compounds $(20 \mu \mathrm{M})$ and their proliferation was evaluated using MTT assay (see Supplementary Materials) [29,30]. 


\subsection{Biological Evaluation for Human Cancer Cells (BGC-823, MDA-MB-231, HepG2, Kyse30)}

All the cell lines were purchased from the Cell Bank of China Science Academy and the cell lines were incubated at $37{ }^{\circ} \mathrm{C}$ under $5 \% \mathrm{CO}_{2}$ atmosphere by using Dulbecco's modified Eagle's medium (DMEM) supplemented with $100 \mathrm{U} / \mathrm{ml}$ penicillin-streptomycin and $10 \%$ FBS. Cell viability was evaluated with Cell Count Kit-8 (CCK-8) assay kit and exponentially growing cells were seeded at $3-8 \times 10^{3}$ cells per well in 96-well culture plates for $24 \mathrm{~h}$. Cells were treated with increasing concentrations (up to $40 \mu \mathrm{M}$ ) of these compounds for $48 \mathrm{~h}$ and an equal volume of DMSO was used as a control. CCK-8 solution $(10 \mu \mathrm{L})$ was added to each well and the light absorbance was measured at $450 \mathrm{~nm}$ after incubation for another $0.5-4 \mathrm{~h}$. The cell survival values were determined by the PrismPad program [31,32]. Cytotoxic effects of compounds were determined at $40 \mu \mathrm{M}$ for $48 \mathrm{~h}$ in human cancer cells (BGC-823, MDA-MB-231, HepG2, Kyse30) and the effects of all the compounds were determined by CCK-8 assay (see Supplementary Materials).

\subsection{Anti-Inflammatory Activity}

RAW264.7, a mouse macrophage cell line, was cultured in high-glucose DMEM supplemented with $10 \% \mathrm{FBS}, 100 \mathrm{\mu g} / \mathrm{mL}$ streptomycin and $100 \mathrm{U} / \mathrm{mL}$ penicillin at $37^{\circ} \mathrm{C}$ in a humidified environment containing $5 \% \mathrm{CO}_{2}$. RAW264.7 $\left(2 \times 10^{4}\right.$ cells $\left./ \mathrm{mL}\right)$ cells were cultivated overnight into 96-well plates with completed DMEM and treated with DMSO or various concentrations of compounds for $24 \mathrm{~h}$. Then, $10 \mu \mathrm{L}$ CCK-8 solution was added into each well for $1 \mathrm{~h}$ at $37^{\circ} \mathrm{C}$ and the absorbance of each well was recorded at $450 \mathrm{~nm}$ using a microplate reader. The cells (RAW264.7) were pre-treated with different concentrations of compounds for $2 \mathrm{~h}$ and then stimulated with LPS $(1 \mu \mathrm{g} / \mathrm{mL})$ for an additional $4 \mathrm{~h}$. The culture supernatant from each well was collected and assayed with IL-6 ELISA Kit.

\section{Conclusions}

Herein we report the isolation and structural elucidation of five new and two known metabolites from the insect $C$. parva. In addition, antiviral, immunosuppressive, anti-tumor and anti-inflammatory properties of all the isolates were determined. We concluded that only compound 5a could suppress the production of IL-6 in LPS-stimulated RAW264.7 cells in a concentration dependent manner.

Supplementary Materials: The following materials are available online. Figures S1-S5: NMR spectra of 1, Figure S6: HRESIMS of 1, Figure S7: CD spectrum of (+)-1 in methanol, Figure S8: CD spectrum of (-)-1 in methanol. Figure S9: The chiral HPLC chromatogram of compound 1. Figures S10-S15: NMR spectra of 2, Figure S16: HRESIMS of 2, Figure S17: CD spectrum of (+)-2 in methanol, Figure S18: CD spectrum of (-)-2 in methanol, Figure S19: The chiral HPLC chromatogram of compound 2. Figures S20-S24: NMR spectra of 3, Figure S25: HRESIMS of 3, Figure S26: CD spectrum of (+)-3 in methanol, Figure S27: CD spectrum of (-)-3 in methanol, Figure S28: The chiral HPLC chromatogram of compound 3. Figures S29-S33: NMR spectra of 6, Figure S34: HRESIMS of 6, Figure S35: CD spectrum of 6 in methanol. Figures S36-S40: NMR spectra of 7, Figure S41: HRESIMS of 7, Figure S42: CD spectrum of 7 in methanol. Figure S43. HPLC analysis of the derivatives of compounds 6, 7, D-ribose, and L-ribose. Figures S44-S47: The chiral HPLC analysis of 6. Figures S48-S51: The chiral HPLC analysis of 7. Figure S52. Anti-HSV-1/F activity assay results of compounds 1-7. Figure S53. Cytotoxicity of compounds 1-7 in naive T Cells. Figure S54. Effect of compounds 1-7 on IFN- $\gamma$ signaling in mouse T cells in vitro. Figure S55. Effect of compounds 1-7 in T-cell proliferation and activation activated by Con A. Figure S56. Cytotoxic effects of compounds 1-7 in human cancer cells.

Author Contributions: Y.-X.C. designed this research. H.C. isolated the compounds and edited the paper. Y.-M.Y. carried out the structure elucidation and edited the paper. D.-W.W. carried out the biological activities assay. Y.-X.C. revised this manuscript. All authors have read and agreed to the published version of the manuscript. 
Funding: This research was funded by National Natural Science Foundation of China (81773603), National Science Fund for Distinguished Young Scholars (81525026), Shenzhen Government's Plan of Science and Technology (JCYJ20170412110504956), Shenzhen Fundamental Research Program (JCYJ20200109114225087), SZU Top Ranking Project (86000000210), Guangdong Key Laboratory for Functional Substances in Medicinal Edible Resources and Healthcare Products (2021B1212040015) and Guangdong-Joint Foundation of Shenzhen (2020B1515120051) for financial support.

Data Availability Statement: Data is contained within the article or supplementary material.

Conflicts of Interest: The authors declare no conflict of interest.

Sample Availability: Samples of the compounds 1-7 are available from the authors.

\section{References}

1. Newman, D.J.; Cragg, G.M. Natural products as sources of new drugs over the nearly four decades from $01 / 1981$ to $09 / 2019$. J. Nat. Prod. 2020, 83, 770-803. [CrossRef]

2. Sun, G.; Hu, C.Q.; Mei, Q.; Luo, M.H.; Chen, X.; Li, Z.Y.; Liu, Y.Z.; Deng, Z.X.; Zhang, Z.Y.; Sun, Y.H. Uncovering the cytochrome P450-catalyzed methylenedioxy bridge formation in streptovaricins biosynthesis. Nat. Commun. 2020, 11, 4501. [CrossRef] [PubMed]

3. Dossy, A.D. Insects and their chemical weaponry: New potential for drug discovery. Nat. Prod. Rep. 2010, 27, 1737-1757. [CrossRef]

4. Seabrooks, L.; Hu, L.Q. Insects: An underrepresented resource for the discovery of biologically active natural products. Acta Pharm Sin. B. 2017, 7, 409-426. [CrossRef] [PubMed]

5. Luo, S.L.; Huang, X.J.; Wang, Y.; Jiang, R.W.; Wang, L.; Bai, L.L.; Peng, Q.L.; Song, C.L.; Zhang, D.M.; Ye, W.C. Isocoumarins from American cockroach (Periplaneta americana) and their cytotoxic activities. Fitoterapia 2014, 95, 115-120. [CrossRef] [PubMed]

6. Bai, H.F.; Li, Y.P.; Qin, F.Y.; Yan, Y.M.; Wang, S.M.; Zhang, H.X.; Cheng, Y.X. Periplanetols A-F, phenolic compounds from Periplaneta americana with potent COX-2 inhibitory activity. Fitoterapia 2020, 143, 104589. [CrossRef]

7. Tang, J.J.; Zhang, L.; Jiang, L.P.; Di, L.; Yan, Y.M.; Tu, Z.C.; Yang, C.P.; Zuo, Z.L.; Hou, B.; Xia, H.L.; et al. Dopamine derivatives from the insect Polyrhachis dives as inhibitors of ROCK1/2 and stimulators of neural stem cell proliferation. Tetrahedron 2014, 70, 8852-8857. [CrossRef]

8. Tang, J.J.; Fang, P.; Xia, H.L.; Tu, Z.C.; Hou, B.Y.; Yan, Y.M.; Di, L.; Zhang, L.; Cheng, Y.X. Constituents from the edible Chinese black ants (Polyrhachis dives) showing protective effect on rat mesangial cells and anti-inflammatory activity. Food Res. Int. 2015, 67, 163-168. [CrossRef]

9. Zhu, H.J.; Xu, T.; Yan, Y.M.; Cheng, Y.X. Nonpeptidal compounds from the insect Polyphaga plancyi and their biological evaluation. Bioorg. Chem. 2020, 104, 104258. [CrossRef]

10. Yan, Y.M.; Zhu, H.J.; Zhou, F.J.; Tu, Z.C.; Cheng, Y.X. Phenolic compounds from the insect Blaps japanensis with inhibitory activities towards cancer cells, COX-2, ROCK1 and JAK3. Tetrahedron 2019, 75, 1029-1033. [CrossRef]

11. Yan, Y.M.; Xu, T.; Tu, Z.C.; Zhu, H.J.; Cheng, Y.X. Sulfur and nitrogen-containing compounds from the whole bodies of Blaps Japanensis. Bioorg. Chem. 2020, 102, 104086. [CrossRef]

12. Song, Z.W.; Yin, W.P.; Liu, P.; Dong, J.F.; Jiang, Y.L.; Gao, T. Advances in chemical constituents and pharmacological effects of familiar Pentatomoids. Chin. J. Appl. Entomol. 2011, 48, 753-756.

13. Yang, Z.H.; Yang, X.Y.; Yuan, X.H.; Luo, K.M.; Luo, X.Y.; Zhang, Y.J.; Guo, Y.L.; Pei, Y. Purification of the antimicrobial peptide AMP-1 of Cyclopelta parva distant by HPLC. J. Southwest Agric. Univ. 2001, 23, 104-107.

14. Wu, Y.F.; Cao, M.L.; Tan, J.; Guo, J.J. Comparison of the inhibitory effects between Aspongopus chinensis and Cyclopelta parva on proliferation of human gastric cancer cell SGC-7901. J. Mountain Agric. Bilo. 2018, 37, 11-14. [CrossRef]

15. Di, L.; Shi, Y.N.; Yan, Y.M.; Jiang, L.P.; Hou, B.; Wang, X.L.; Zuo, Z.L.; Chen, Y.B.; Yang, C.P.; Cheng, Y.X. Nonpeptide small molecules from the insect Aspongopus chinensis and their neural stem cell proliferation stimulating properties. RSC Adv. 2015, 5, 70985-70991. [CrossRef]

16. Shi, Y.N.; Tu, Z.C.; Wang, X.L.; Yan, Y.M.; Fang, P.; Zuo, Z.L.; Hou, B.; Yang, T.H.; Cheng, Y.X. Bioactive compounds from the insect Aspongopus chinensis. Bioorg. Med. Chem. Lett. 2014, 24, 5164-5169. [CrossRef]

17. Yan, Y.M.; Ai, J.; Shi, Y.N.; Zuo, Z.L.; Hou, B.; Luo, J.; Cheng, Y.X. ( \pm )-Aspongamide A, an N-acetyldopamine trimer isolated from the insect Aspongopus chinensis, is an inhibitor of p-Smad3. Org. Lett. 2014, 16, 532-535. [CrossRef]

18. Li, J.; Li, Y.P.; Qin, F.Y.; Yan, Y.M.; Zhang, H.X.; Cheng, Y.X. Racemic xanthine and dihydroxydopamine conjugates from Cyclopelta parva and their COX-2 inhibitory activity. Fitoterapia 2020, 142, 104534. [CrossRef]

19. Yeh, G.C.; Henderson, J.P.; Byun, J.; Avignon, D.A.; Heineckeb, J.W. 8-Nitroxanthine, a product of myeloperoxidase, peroxynitrite, and activated human neutrophils, enhances generation of superoxide by xanthine oxidase. Arch. Biochem. Biophys. 2003, 418, 1-12. [CrossRef]

20. Ding, W.Y.; Yan, Y.M.; Meng, X.H.; Nafie, L.A.; Xu, T.; Dukor, R.K.; Qin, H.B.; Cheng, Y.X. Isolation, total synthesis, and absolute configuration determination of renoprotective dimeric $N$-acetyldopamine-adenine hybrids from the insect Aspongopus chinensis. Org. Lett. 2020, 22, 5726-5730. [CrossRef] 
21. Wang, C.X.; Chen, G.D.; Feng, C.C.; He, R.R.; Qin, S.Y.; Hu, D.; Chen, H.R.; Liu, X.Z.; Yao, X.S.; Gao, H. Same data, different structures: Diastereoisomers with substantially identical NMR data from nature. Chem. Commun. 2016, 52, 1250-1253. [CrossRef] [PubMed]

22. Yao, C.P.; Zhou, Z.X.; Zhang, Y.; Li, J.; Cheng, F.; Xu, P.S.; Zhou, G.; Li, X.M.; Xu, K.P.; Tan, G.S. New adenine analogues and a pyrrole alkaloid from Selaginella delicatula. Nat. Prod. Res. 2019, 33, 1985-1991. [CrossRef]

23. Tietze, L.F.; Bell, H.P.; Chandasekhar, S. Natural product hybrids as new leads for drug discovery. Angew. Chem. Int. Ed. 2003, 115, 4128-4160. [CrossRef]

24. Walsh, J.J.; Coughlan, D.; Heneghan, N.; Gaynor, C.; Bell, A. A novel artemisinin-quinine hybrid with potent antimalarial activity. Bioorg. Med. Chem. Lett. 2001, 17, 3599-3602. [CrossRef]

25. Tanaka, T.; Nakashima, T.; Ueda, T.; Tomii, K.; Kouno, I. Facile discrimination of aldose enantiomers by reversed-phase HPLC. Chem. Pharm. Bull. 2007, 55, 899-901. [CrossRef] [PubMed]

26. Yan, Y.M.; Luo, Q.; Di, L.; Shi, Y.N.; Tu, Z.C.; Cheng, Y.X. Nucleoside and N-acetyldopamine derivatives from the insect Aspongopus chinensis. Fitoterapia 2019, 132, 82-87. [CrossRef]

27. Frisch, M.J.; Trucks, G.W.; Schlegel, H.B.; Scuseria, G.E.; Robb, M.A.; Cheeseman, J.R.; Scalmani, G.; Barone, V.; Mennucci, B.; Petersson, G.A.; et al. Gaussian, Version 09, Expanding the Limits of Computational Chemistry; Gaussian, Inc.: Wallingford, CT, USA, 2013.

28. Xiang, Y.F.; Pei, Y.; Qu, C.; Lai, Z.C.; Ren, Z.; Yang, K.; Xiong, S.; Zhang, Y.J.; Yang, C.R.; Wang, D.; et al. In vitro anti-herpes simplex virus activity of 1,2,4,6-tetra-O-galloyl-D-glucose from Phyllanthus emblica L. (Euphorbiaceae). Phytother. Res. 2011, 25, 975-982. [CrossRef] [PubMed]

29. Jakhar, R.; Sharma, C.; Paul, S.; Kang, S.C. Immunosuppressive potential of astemizole against LPS activated T cell proliferation and cytokine secretion in RAW macrophages, zebrafish larvae and mouse splenocytes by modulating MAPK signaling pathway. Int. Immunopharmacol. 2018, 65, 268-278. [CrossRef]

30. Chen, F.Y.; Ni, Y.; Ye, Y.P.; Sun, H.X.; Li, X.Y.; Xu, S.F. Stephanthraniline A inhibits the proliferation and activation of T cells in vitro and in vivo. Eur. J. Pharmacol. 2012, 685, 186-197. [CrossRef]

31. Wang, W.; Wang, C.Y. Integrated miRNA and mRNA omics reveal the anti-cancerous mechanism of Licochalcone B on Human Hepatoma Cell HepG2. Food Chem. Toxicil. 2021, 150, 112096. [CrossRef]

32. Hasanpourghadia, M.; Majidb, N.A.; Mustafaa, M.R. Activation of autophagy by stress-activated signals as a cellular self-defense mechanism against the cytotoxic effects of MBIC in human breast cancer cells in vitro. Biochem. Pharmacol. 2018, 1552, 174-186. [CrossRef] [PubMed] 